\title{
Physical Changes in World Heritage Sites under the Pressure of Tourism: The Case of Cumalik1z1k Village in Bursa
}

\author{
Elif Acar Bilgin ${ }^{1}$, Tülin Vural Arslan ${ }^{1}$ and Selen Durak ${ }^{1}$
}

\begin{abstract}
Bursa, the first capital city of Ottoman Empire, was inscribed into UNESCO World Heritage List in 2014 with Khans Area, Sultan Complexes (Kulliyes) and Cumalıkız1k village representing the relationship between urban and rural areas of Early Ottoman Period. Cumalıkızık Village is one of the most popular rural settlements in Bursa which maintains its urban fabric, road pattern, and traditional houses. Under the pressure of increasing tourism, traditional houses began to be used for commercial purposes with the interventions made by their owners which threatens the sustainability and preservation of their authenticity and integrity. This paper aims to determine the interventions in historic dwellings and courtyards due to tourism. For this purpose, three historic houses on the most visited sightseeing route starting from the village square, continuing along the nodes of the settlement following the mosque and the hammam (public bath) to examine the physical changes under the effect of tourism.
\end{abstract}

Keywords: cultural tourism; rural heritage; world heritage sites; Cumalıkızlk; Bursa

\section{Introduction}

According to the United Nations World Tourism Organization (UNWTO, 2014), tourism is a social, cultural and economic phenomenon leading people move to places or countries outside of their usual environments for personal or working/professional purposes.

Cultural tourism is the sharing of tangible and intangible cultural heritage such as landscapes, buildings, collections, art, identity, tradition, language. Cultural tourism plays an important role in understanding and protecting the value of not only architectural but also cultural heritage such as language, belief and traditions. It is a way of understanding and introducing intercultural interaction and cultural diversity (EU Sustainable Tourism Guidelines, 2009).

Cultural tourism has the aim of watching and participating in archaeological sites and museums, architectural places, art galleries, festivals, sculptures, music and dance activities, theater performances and religious festivals. Cultural tourism does not only have an effect on the protection of historical and cultural heritage of places where it grows, but it also yields profits economically (Uygur \& Baykan, 2007). In addition to this, such positive aspects as spreading investments country-wide rather than gathering at certain points, encouraging environment-friendly investments and achieving the 
protection of historical and cultural heritage make cultural tourism attractive (Özdemir, 2009).

Cultural tourism is an important phenomenon in terms of not only keeping the traditional housing fabric in rural areas alive but also encouraging the achievement of economic growth and socio-cultural sustainability. When agricultural production falls short of meeting necessary living conditions, additional sectors like tourism step in and make a contribution to economic development. With types of tourism planned by also taking the protection of natural and cultural values into consideration, development of rural areas can be achieved (Gürer, 2003).

While it is an important tool for the encouragement of the sustainability of cultural tourism, it may turn into a negative factor in some cases, too, as a result of such factors as over-commercialization, visitor pressure, increasing increasing unearned income value brought about by tourism as well. In this article, in order to investigate the effects of cultural tourism on rural architecture, the Village of Cumalık1zik, Bursa's World Heritage rural area, was chosen as the working area. Besides the restoration works made by the local administrations, functional changes realized in rural architecture developing and changing under the effect of tourism and their effects on their authenticity and integration were also discussed.

\section{Effects of Cultural Tourism on Historical Settlements}

Today's people prefer to be culture tourists of the twenty-first century and want to relax by experiencing new places and enriching their lives. Besides personal benefits, tourism supports many historical settlements in various ways as well. Cultural tourism contributes to the rise of local and national income in historical settlements, the making of investments in historical places, the re-use of historical buildings, the keeping of local traditions and activities alive and the supporting of local productions such as foods, drinks and handicrafts. Tourism may also turn into a problem for historical settlements. Physical environment may be damaged, the spirit and cultural identity of the settlement may be spoilt and tourism movements may become a difficulty for local people by leading to inflation. Moreover, it may also cause environmental problems such as environmental pollution, decrease of renewable resources and climate change. For example, waste waters of hotels and excessive energy use, carbon dioxide emission are some of the effects of tourism on the environment (EU Sustainable Tourism Guidelines, 2009).

In many societies, there is a perception that tourism has a negative effect on cultures and societies. One the one hand, tourism has a negative effect on cultural property and local resources, but on the other hand it may be a source of income for the society. Acknowledging economic development most of the time means acknowledging cultural change depending on the development of tourism as well. Local people's contentment of tourism has a critical role in terms of sustainability (World Tourism Organization [WTO], 2014).

Tourism prevailing in rural areas causes a change in the settlement pattern. There should be a balance between profitmaking depending on tourism and cultural values forming the identity. Both local people and visiting tourists have a responsibility in 
the protection of local identity. In the planning of tourism, the sustainability of cultural diversity and authenticity should be one of the primary targets (Uslu \& Kiper, 2006).

Tourism has both positive and negative effects on the sustainable use of the traditional structures especially in cultural heritage areas having become important tourism centres. The local/traditional structures used for touristic accommodation purposes in many cities face the danger of losing their authenticity. On the other hand, they contribute to the restoration of buildings by providing resource increase. While tourism is developing, traditional structures change in formal, functional and cultural sense. Structures both serve the use of local people in daily life and, at the same time, are the means of attraction for tourists. Taking transformations done for needs of tourists under control will prevent local life from being damaged in the long term. If the sustainability of local people and traditional lifestyle cannot be achieved, cultural heritage areas will lose their authenticity and attraction. The sustainable tourism for cultural heritage areas means the sustainability of not only physical environment but also lifestyle. For the sustainable use of traditional structures, harmonious use has an important role (Zhang, Yamamura \& Fujiki, 2006).

Together with the start of the understanding that tourism activities have negative effects on natural and cultural resources and these effects put the future of tourism into danger, the understanding of sustainability has reflected to tourism. Distribution of the benefits of tourism among regions and layers of society in a balanced way underlies the concept of sustainable tourism and this situation also contributes to the elimination of poverty (Durak, 2014).

In 2009, European Association of Historic Towns and Regions determined the 'Principles for Sustainable Tourism in Historical Settlements and Cities'. These principles can be summarized as follows: making cultural tourism environment-friendly and sustainable; keeping the real value of historical heritage above tourism revenues; respecting and maintaining the authenticity of local cultures; making a contribution to the protection of historical heritage; providing local people with advantages; being able to meet the needs of visitors; sustainable planning of transportation to the area and within-area transportation (EU Sustainable Tourism Guidelines, 2009).

In order to measure the effects of tourism activities in cultural property areas, some indicators were developed by the World Tourism Organization-WTO in various subjects and published a book. These indicators (WTO, 2014) were gathered under five headings, namely:

- effects of tourism on the society,

- sustaining cultural property and protecting heritage,

- achieving local people's participation and awareness,

- controlling touristic activities and using density,

- management of activities.

The indicators related to effects on society are local people's participation in tourism, benefiting from social services, tourist numbers, changes in locals' lifestyles due to transitions from traditional occupations to the tourism sector, housing problems and changes in population. The indicators related to the protection and sustaining of cultural heritage are discussed under the main headings of sites, monuments, structural 
deteriorations, maintenance and repair, introduction, protection. Policies, legal regulations related to the protection of cultural property, financial resources allocated for restoration works, publications for the introduction of cultural property, increases and decreases in the number of factors threatening the integrity and authenticity of cultural property and the authentic use of the site are also mentioned among important indicators (WTO, 2004).

\section{Change in Cumalıkızık under the Effect of Tourism}

\subsection{History of Cumalıkızık and Traditional Settlement Pattern}

Cumalıkızık is an Ottoman village in the east of Bursa, within the borders of the district of Yildirim and on the northern outskirts of Uludag. This village is one of the few villages having reached today by preserving its traditional settlement texture and authenticity, social structure in Bursa (Fig. 1, Fig. 2). The Village of Cumalıkizik as an example of the Early Ottoman period city-village relationship inscribed on to the UNESCO World Heritage List together with the Commercial Districts of Khans and the Sultan Kulliyes located in the city centre of Bursa in 2014 by fulfilling the selection criteria $^{1}$ numbered i, ii, iii, iv and vi with the file entitled "Bursa and Cumalikızik: The Birth of the Ottoman Empire". The Village of Cumalıkızk fulfilled the criterion numbered iii 'as a good example of the early Ottoman life and vision with the handicraftsman culture living today and also with the sustainability of rural life so close to the city' (Bursa Site Management Unit, 2013a).

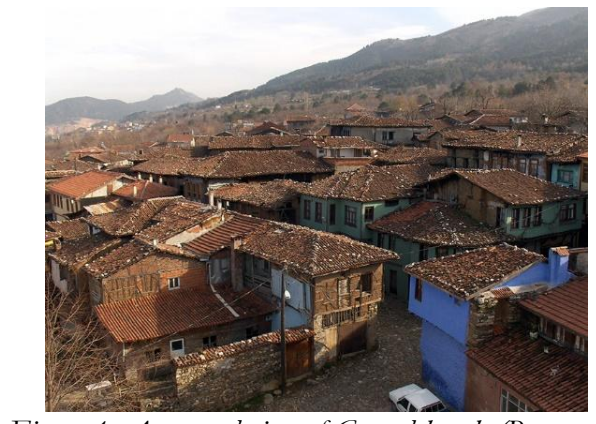

Figure 1. A general view of Cumalıkrzlk (Bursa Site Management Unit, 2019)

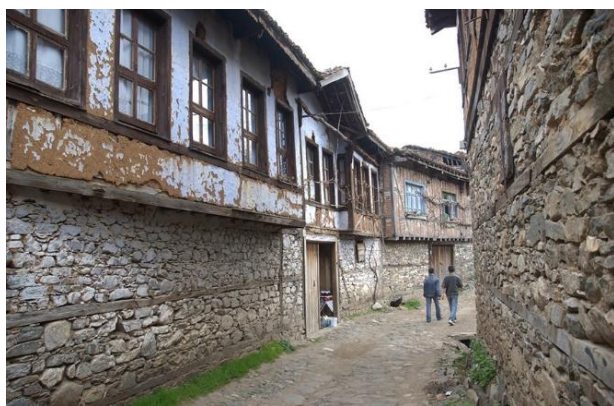

Figure 2. A street view of Cumallkı̨lk (Bursa Site Management Unit, 2019)

The monuments, a mosque, a public bath, tombs, village cemetery and a fountain in the Village of Cumalikizık are located within the World Heritage core area. Moreover, 123 of 176 structures, which are the examples of the traditional civil architecture, are registered. And as a natural heritage, there are also 3 registered monumental trees (Bursa Site Management Unit, 2013a). With its organic street texture, monumental structures, historical houses, agricultural areas and, most importantly, people protecting these, Cumalık1z1k is still one of the best-preserved examples of the Ottoman rural architecture bearing the village characteristic. The natural stone paved streets of the village are authentic. Moreover, today, the village's current water and sewerage systems are protecting their authenticity left from the period when they were 
first built and still meeting the needs (Bursa Site Management Unit, 2013b). The square at the entry to the village where there are monumental plane trees, the mosque square and the public bath are the focal points of the settlement (Fig. 3, Fig. 4).

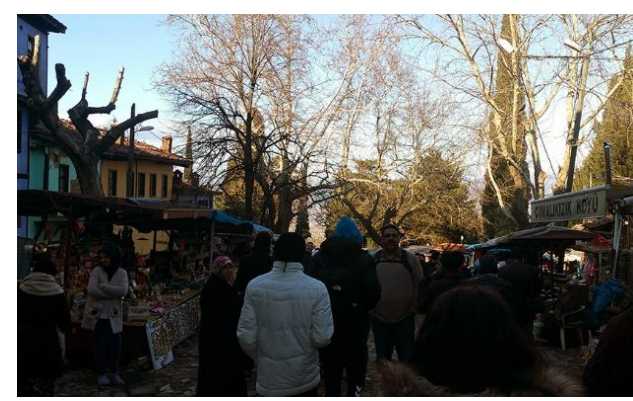

Figure 3. Town square of Cumalikıılk at weekend (Source: the Authors)



Figure 4. Town square of Cumallkizle during weekday (Source: the Authors)

\subsection{Cumalıkızı within the Scope of Sustainable Tourism}

The Village of Cumalikizik is one of the best-preserved examples of the rural architecture in Turkey. It became a subject for the academic studies at universities in the 1990's. In addition to taking place in a domestic TV series, its public recognition level increased at the national scale and it became a focus of interest for local tourists. Having turned into an open air museum and a commercial area, the Village of Cumalikizik is providing service for same-day and accommodation tourism today as well. Both having been preserved and being close to the city centre has always been an advantage for Cumalıkı1k. And the villagers deriving income from tourism have started to pay attention to the protection of the village (Eres, 2016).

As Cumalıkızık have become a focal point in the sense of tourism, the houses have started to be used commercially, the ground floors and the inner courts have turned into Turkish pancake houses, local foods started to be sold at the stalls opened in front of the houses and in the square at the entry to the village. In the village, two guesthouses were opened by the Municipality of Yıldırım and in a private property (Gürer, 2003). Today, these two guest-houses are providing service. Since the village is visited mostly for day-trip purposes, the number of guest-houses has not changed. Tourists mostly stay at the hotels in the city centre. In the land use map section prepared in 2012 and taking place in the Management Plan (2013b), there are two structures taking place in the village square and shown as having a commercial function, one structure next to the public bath, a grocery store opposite the mosque and a breakfast house and a guesthouse. On the contrary, the village people desiring to benefit from the increasing tourism potential are giving service by turning the ground floors of their houses generally into small cafes where Turkish pancakes are made. In the functional analysis made in 2016 in the same region, it was observed that the structures having been used as dwelling houses previously turned into commercial functions. In this study, the structures with ground floors having started to be used commercially were analysed. 


\subsection{Physical Change of Cumalikız1k under the Effect of Tourism}

With the rise of tourism after the 2000's and especially starting from 2014, the ground floors of the dwelling houses have started to be used as breakfast and Turkish pancake houses or souvenir shops. Hence, the local people have started to derive income from same-day tourism. The upper stories are continuing to be used for dwelling purposes. Moreover, in the inner courts, which are a characteristic of the region, annexes having such functions as wet area, kitchen and sitting area were built for touristic purposes.

In this section, the sighting route starting from the village square, continuing along the streets where the mosque and the public bath are and used most frequently and coming to the village square again was specified. On this route, physical changes made under the effect of tourism were examined over example structures. One of the chosen examples is in the village square (Case 1), the second one is opposite the mosque (Case 2) and the third one is next to the public bath (Case 3). The reason of choosing them is to determine the repairs and modifications made by the building owners under the effect of tourism (Fig. 5).

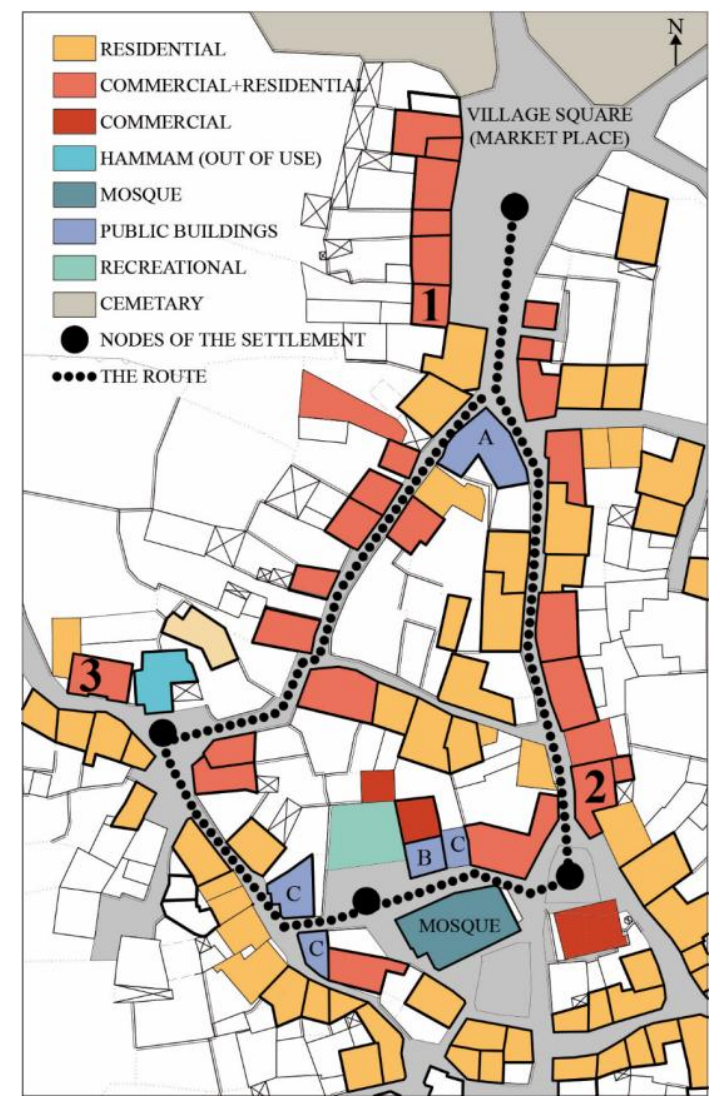

Figure 5. Function analysis of historical buildings on the most visited route in Cumalikrzle (A: Cultural Center, B: Ethnography Museum, C: Local Associations) (Adapted by the Authors from the maps in Bursa Site Management Unit, 2013b) 


\subsubsection{Case Analysis 1}

The building is in the town square, on the Eğrek Street. The building has a NEW two-winged iron gate. A seating arrangement was made in the inner court and in front of the house and is used as a food court. (Fig. 6). Under the effect of tourism, the first change was made on the ground floor and in the use of courtyard (Fig. 7). The authentic housing structure is facing the street and the backyard is reached by passing through the entrance courtyard. The dwelling use in the ground floor of this building is going on. The stable built in the inner court next to the house was turned into a kitchen and a bathroom later.

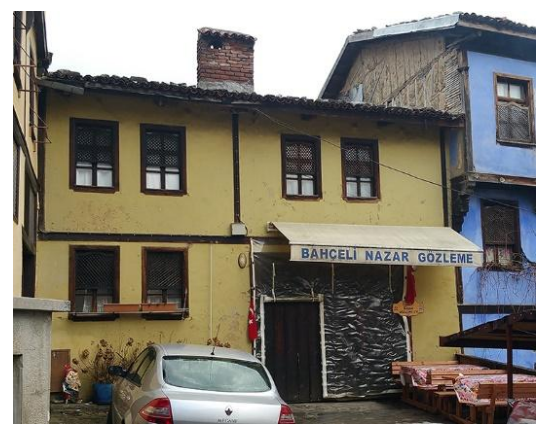

Figure 6. Case 1-Front facade of the house (Source: the Authors)



Figure 7. Case 1-Traditional house and the annex in the backyard (Source: the Authors)

A two-storey concrete building was built in the backyard. The ground floor of the two-storied building built in the inner court is being used as a kitchen and the upstairs is being used as a store-room (Fig. 8). The stone walls of the entrance courtyard were covered with wooden siding, the shelves were placed and turned into places where souvenirs are sold (Fig. 9).

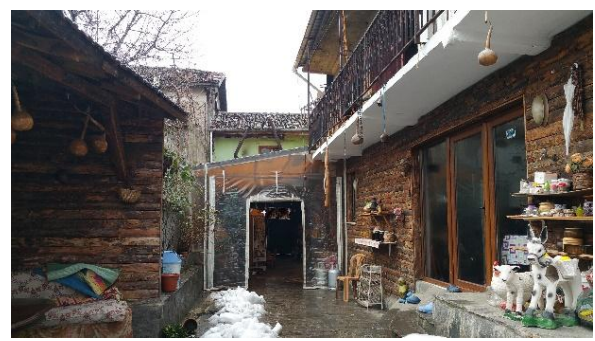

Figure 8. New reinforced concrete building in the backyard (Source: the Authors)

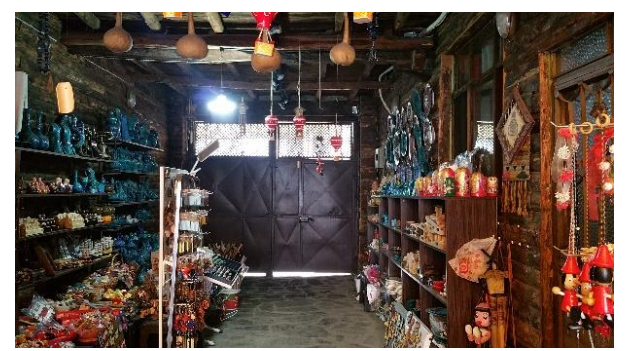

Figure 9. Wooden siding on the masonry walls of ground floor (Source: the Authors)

\subsubsection{Case Analysis 2}

The building is located on Orta Street one of the nodes of settlement in front of the mosque. At present, the repairs and modifications in the building were made by the homeowners. A spacious window was opened next to the entrance gate and a folding sunshade was mounted over the window on the façade (Fig. 10). The entrance courtyard 
in the ground floor was arranged as a breakfast and Turkish pancake house and a singlestoried kitchen was added to the backyard of the house (Fig. 11, Fig. 12, Fig. 13). The upper storey of the structure is being used for dwelling purposes. In case of a need, antre-room (sofa) of the upper storey also serves as a breakfast hall.

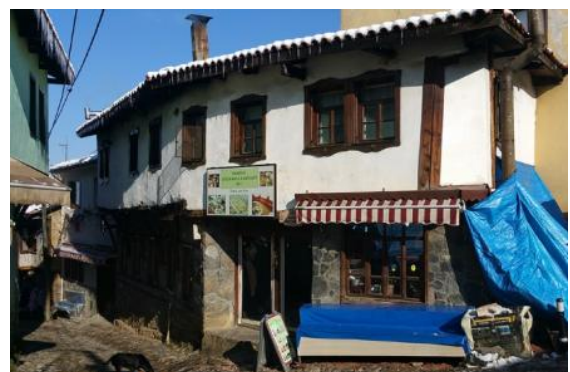

Figure 10. Case 2-Front facade of the house (Source: the Authors)

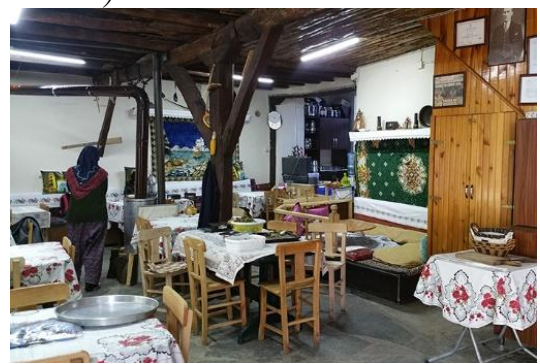

Figure 12. The ground floor of house refunctioned for commercial use (Source: the Authors)

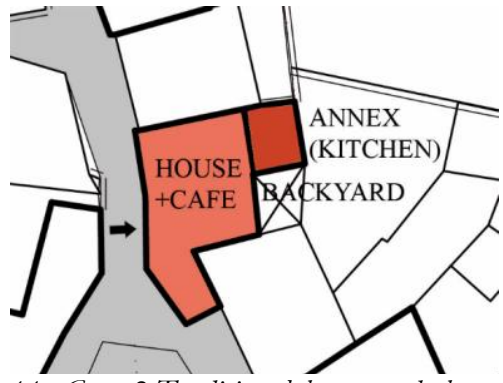

Figure 11. Case 2-Traditional house and the annex in the backyard (Source: the Authors)

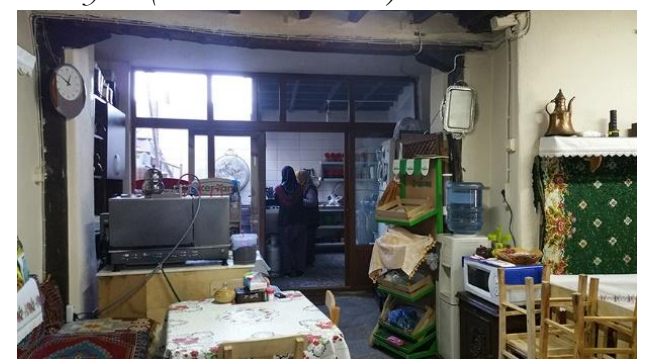

Figure 13. The new kitchen built in the backyard (Source: the Authors)

Since it started to be used as Turkish pancake house, new windows were mounted on the ground floor walls (Fig. 14). The owners of the building stated that there had been two small-sized windows at an elevation above the eye level on the wall of the entrance courtyard facing the street prior to this repair. One of the factors shaping the traditional Anatolian dwelling house is the concept of privacy. The ground floor walls without openings, which is a reflection of this concept, have lost their authenticity with the intervention made in this structure. The wooden stairs were renewed and the entrance of the house was separated from the commercial area by covering the surroundings of the stairs (Fig. 15).

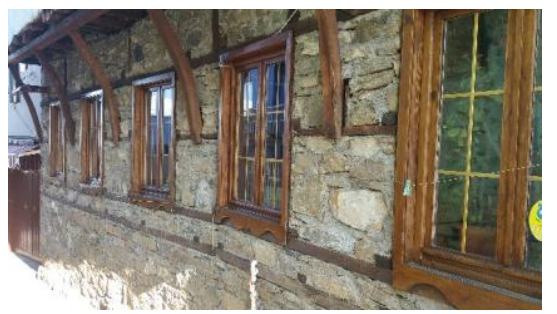

Figure 14. New openings on the ground floor walls (Source: the Authors)



Figure 15. Entrance of house closed by wooden separator in the ground floor (Source: the Authors) 


\subsubsection{Case Analysis 3}

The structure is on the Hammam Street, next to the Cumalik1zik Hammam (Public bath). This building and the close environment were used as a TV serial studio in 2002 and made Cumalikizik promoted (Fig. 16). The authentic house is facing the street and the inner courtyard is reached by passing through the entrance courtyard. A new house has been built near the historic house with a separate entrance from the street. A two-storeyed with the wooden floor carried by the wooden pillars was added to the inner courtyard (Fig. 17). A part of the inner court is used as a kitchen and another part is used as a dining hall (Fig. 18, Fig. 19).

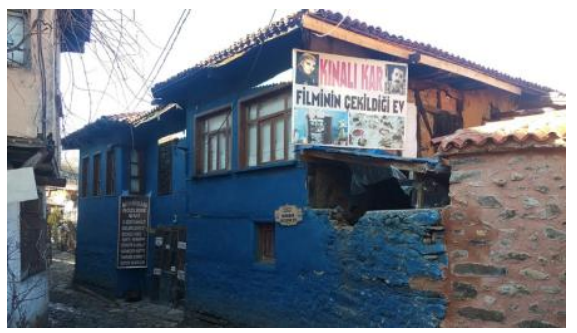

Figure 16. Case 3-Front facade of the traditional house near the historic hammam (Source: the Authors)

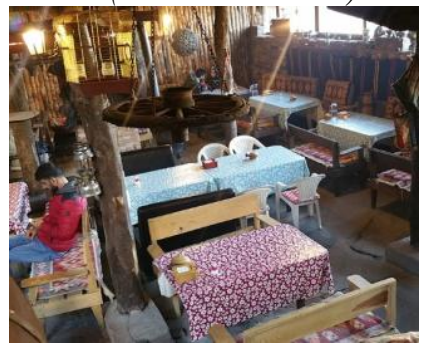

Figure 18. New commercial use in the inner court of ground floor (Source: the Authors)

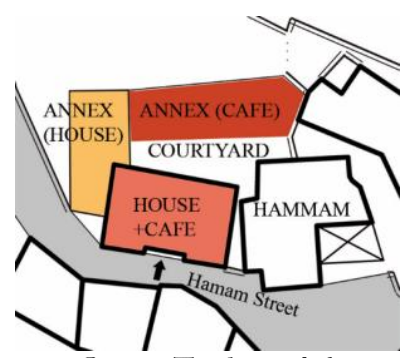

Figure 17. Case 3-Traditional house and the annexes in the courtyard (Source: the Authors)

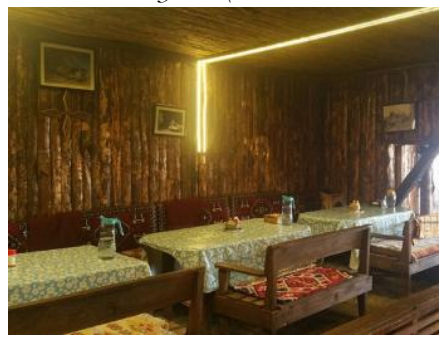

Figure 19. New wooden siding on the masonry walls of ground floor (Source: the Authors)

The upper storey of the annex is used as the dining room. On the first floor, the open antre-room (sofa) of the authentic house facing the inner courtyard was closed by this annex (Figs. 18-22). As a result of the functional change made in the use of the ground floor and annex built for commercial purposes, the open courtyard of the structure was turned into a closed area.

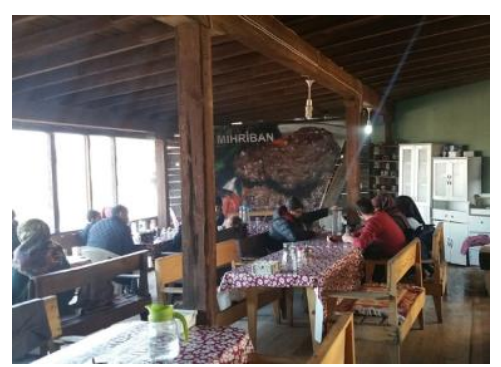

Figure 20. The dining ball in the upper storey of the annex (Source: the Authors)

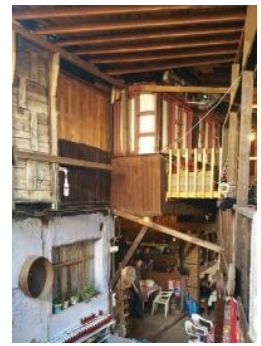

Figure 21. The open anteroom is closed due to annex (Source: the Authors) 


\section{Evaluation and Conclusion}

One of the significant factors that enable Bursa and Cumalik1zik to be inscribed as a World Heritage Site is the fact that they are the unique examples of city-village-waqf system relationship of Early Ottoman Period. Besides this characteristic, Cumalıkızk has reached today by preserving its authenticity and integrity in terms of settlement and building scale.

The houses of Cumalikizik reflect the plan and facade characteristics of the traditional Anatolian house, the street courtyard house relationship and the use of ground floor shaped by rural production style. The interventions made by the homeowners for giving service for tourists without taking scientific support are posing a threat for the typological characteristics and authenticity of Cumalıkızik, which are outstanding universal value of the village.

In order to ensure the protection and sustainability of Cumalikız1k, rural tourism should be developed, planning should be made in accordance with the bearing capacity of the region and precautions should be taken against such natural disasters as fire, earthquake. Moreover, measures should be taken against negative effects such as change of property under the effect of tourism, natural resources should be used in balance, the agricultural structure should be preserved and new functions should be given to the current structures by restoring them. The understanding of sustainable conservation and development should be adopted (Gürer, 2003).

Below are given suggestions in relation to the preservation of Cumalikızik against the tourism pressure and the achievement of its sustainable development. These suggestions were gathered under various headings:

Suggestions in relation to the Restorations:

- One of the threats determined in the SWOT analysis (Bursa Site Management Unit, 2013b) made for Cumalık1zik is the structures' having lost their authenticity via incorrect interventions. Arrangements should be made in especially a way not to damage the authentic plan scheme or in a way to ensure the presentation of the authentic plan scheme with the new function in the uses of the ground floor.

- The faculties of architecture in Bursa and the departments of restoration in vocational schools can be encouraged to participate in the restoration applications. Hence, an integrated protection can be achieved by creating a protection process shared by the universities, the local government and the local people.

Suggestions in relation to the Participation of the Local People in the Planning:

- Gürer (2003) carried out a questionnaire study on the tourism sector in Cumalikız1k and the development of rural tourism, and asked questions about different subjects such as household information, working status, means of living, floor and room numbers of the houses, the agricultural products grown, local handicrafts. The change in the status of the local people since 2003 can be determined by repeating a similar questionnaire. Moreover, local people can be made to participate in the process when making management and planning decisions for the future after having been taken in the world heritage list.

Suggestions in relation to the Promotion: 
- Cumalık1zik is included among the tour routes of local and foreign tourists. Visitors come to Cumalıkızı mostly for taking a walk in the streets, taking photos and consuming or buying local foods. The outstanding universal value of Cumalık1z1k stated with the concepts of authenticity and integrity is not yet understandable and perceivable for many people touring the area. Excursions cannot go beyond taking photographs in the streets and eating. For this reason, tours in which the history of the village, the traditional settlement pattern and the housing typology can be more informative.

- It is necessary to raise awareness of tourists about the historic, cultural, social and architectural values of the village by acknowledging them. With this aim, Cumalikızk Cultural Centre, located in the village square, can be organized to include a "Tourism Information Centre". Tour guides can be employed to make presentations in different languages for tourists. Also, a brochure including a tour map, a tour route and necessary information can be prepared to guide tourists during excursions.

- One of the typical houses in Cumalik1zik can be used as a "museum+house" in which both authentic rural life continues and exhibitions about plan typologies displaying multifunctional ground floor use and the differences in winter-summer use, and the effect of agricultural production on the formation of the houses are organized. Measures can be taken in order to sustain the rural life of the village with the existing agricultural production.

Suggestions related to Activities:

- In addition to the Raspberry Festival held every year in July, alternative outdoor sports and activities such as trekking, mountain bike tours can be planned and the diversity of visitors can be increased.

Suggestions related to Publication Works:

- Publications of studies carried out, the building survey, restitution and restoration reports of every structure should be incorporated into a booklet and should be shared with the public. Moreover, a typology and inventory study covering the whole village can be made and incorporated into a book.

In conclusion, the authenticity and integrity of the architectural heritage, which is the most important component of the cultural heritage, should be preserved. While tourism is improving, the unexpected changes should be taken under control through projecting negative effects of tourism on the identity and buildings of the settlement by considering the existing condition and the capacity of the area. Prior to the works to be performed by the local authorities, the commercial interventions made by the local people should be monitored. Cultural heritage is a tool for the development of cultural tourism. While tourism is developing, cultural heritage should not be commodified, but its protection should be aimed.

\section{Notes}

1. World Heritage Selection Criteria: (i) to represent a masterpiece of human creative genius; (ii) to exhibit an important interchange of human values, over a span of time or within a cultural area of the world, on developments in architecture or technology, monumental arts, town-planning or landscape design; (iii) to bear a unique or at least exceptional testimony to a cultural tradition or to a civilization 
which is living or which has disappeared; (iv) to be an outstanding example of a type of building, architectural or technological ensemble or landscape which illustrates (a) significant stage(s) in human history; (v) to be an outstanding example of a traditional human settlement, land-use, or sea-use which is representative of a culture (or cultures), or human interaction with the environment especially when it has become vulnerable under the impact of irreversible change; (vi) to be directly or tangibly associated with events or living traditions, with ideas, or with beliefs, with artistic and literary works of outstanding universal significance (http://whc.unesco.org/en/criteria/).

\section{References}

Bursa Site Management Unit (2013a). Dünya Mirası Adaylık Dosyas1, Bursa ve Cumalıkızık: Osmanlı İmparatorluğu'nun Doğuşu [World Heritage Nomination File. Bursa and Cumalıkızık: The Birth of the Ottoman Empire]. Bursa Metropolitan Municipality, Bursa.

Bursa Site Management Unit (2013b). Bursa ve Cumalıkızık Yönetim Planı [Bursa and Cumalıkızık Management Plan (2013-2018)]. Bursa Metroplitan Municipality, Bursa. Retrieved from http://alanbaskanligi.bursa.bel.tr/unesco/yonetim-plani/ (Access Date: 30.06.2017)

Bursa Site Management Unit. (2019) Photo Gallery of Bursa Site Management Unit, [online], http://alanbaskanligi.bursa.bel.tr/fotograf-arsivi/, (Access Date: 08.03.2019).

Durak, Ş. (2014). Tarihi Çevrelerde Sürdürülebilir Turizm Planlaması: Diyarbakır Tarihi Sur İçi Bölgesi Örneği [Sustainable Tourism Planning in the Historical Environments: Case of Diyarbakir Historical Surici Region]. Yüksek Lisans Tezi. Dicle Üniversitesi Fen Bilimleri Enstitüsü Mimarlık Anabilim Dalı.

Eres, Z. (2016). Türkiye'de Geleneksel Köy Mimarisini Koruma Olasılıklar1 [Conservation Possibilities of Traditional Rural Architecture in Turkey]. Ege Mimarlık Dergisi, 92, 8-13.

EU Sustainable Tourism Guidelines. (2009). Guidelines for Sustainable Cultural Tourism in Historic Towns and Cities, European Union European Association Historic Towns and Cities 1-18. Retrieved from http://www.historic-towns.org/documents/downloads/ SustainableTourismGuidelines.pdf (Access Date: 30.06.2017)

Gürer, N. (2003). Kırsal Geleneksel Konu Dokusunun Turizm Bağlaminda Değerlendirilmesi, Cumalıkızık Örneği [The Evaluation of the Rural Traditional Housing Pattern Within the Content of Tourism, Cumalıkızık Case]. Yüksek Lisans Tezi. Gazi Üniversitesi Fen Bilimleri Enstitüsü Şehir ve Bölge Planlama Bölümü.

Özdemir, N. (2009). Kültür Ekonomisi Ve Endüstrileri İle Kültürel Miras Yönetimi İlişkisi [The Relationship Between Cultural Economy and Cultural Heritage Management]. Milli Folklor Dergisi, 84, 73-86.

UNESCO World Heritage Center, The Criteria for Selection. Retrieved from http://whc.unesco.org/en/criteria (Access Date: 30.09.2017).

UNWTO (United Nations World Tourism Organization). 2014. Glossary of Tourism Terms (Last update: February 2014), United Nations World Tourism Organization. Retrieved from http://statistics.unwto.org/sites/all/files/docpdf/glossaryterms.pdf (Access Date: 30.06.2017)

Uslu A., \& Kiper T. (2006). Turizmin Kültürel Miras Üzerine Etkileri: Beypazarı/Ankara Örneğinde Yerel Halkın Farkındalığ [Effects of Tourism on Cultural Heritage: Awareness of Local People in Beypazar1, Ankara]. Tekirdağ Ziraat Fakültesi Dergisi, 3, 305-314.

Uygur S.M., \& Baykan E. (2007). Kültür Turizmi Ve Turizmin Kültürel Varlıklar Üzerindeki Etkileri [Effects of Cultural Tourism on Cultural Assests]. Ticaret ve Turizm Eğitim Fakültesi Dergisi, 2, 30-49.

WTO (World Tourism Organization). (2004). Indicators of Sustainable Development for Tourism Destinations, A Guidebook. Madrid, Spain: World Tourism Organization.

Zhang, T.X., Yamamura, T., \& Fujiki, Y. (2006). Can Vernacular Buildings Survive With Traditional Life Inside And Tourism Outside?. WIT Transactions on Ecology and the Environment, 97, 171-180. WIT Press, www.witpress.com, ISSN 1743-3541 (on-line). 